\title{
Paleomagnetism and U-Pb geochronology of the late Cretaceous Chisulryoung Volcanic Formation, Korea: tectonic evolution of the Korean Peninsula
}

\author{
Doohee Jeong ${ }^{1}$, Yongjae $\mathrm{Yu}^{1 *}$, Seong-Jae Doh², Dongwoo Suk ${ }^{3}$ and Jeongmin Kim ${ }^{4}$
}

\begin{abstract}
Late Cretaceous Chisulryoung Volcanic Formation (CVF) in southeastern Korea contains four ash-flow ignimbrite units ( $\mathrm{A} 1, \mathrm{~A} 2, \mathrm{~A} 3$, and $\mathrm{A} 4)$ and three intervening volcano-sedimentary layers (S1, S2, and S3). Reliable U-Pb ages obtained for zircons from the base and top of the CVF were $72.8 \pm 1.7 \mathrm{Ma}$ and $67.7 \pm 2.1 \mathrm{Ma}$, respectively. Paleomagnetic analysis on pyroclastic units yielded mean magnetic directions and virtual geomagnetic poles (VGPs) as D/I $=19.1^{\circ} / 49.2^{\circ}$ $\left(a_{95}=4.2^{\circ}, k=76.5\right)$ and $V G P=73.1^{\circ} \mathrm{N} / 232.1^{\circ} \mathrm{E}\left(A_{95}=3.7^{\circ}, \mathrm{N}=3\right)$ for $\mathrm{A} 1, \mathrm{D} / \mathrm{I}=24.9^{\circ} / 52.9^{\circ}\left(a_{95}=5.9^{\circ}, \mathrm{k}=61.7\right)$ and $\mathrm{VGP}=69.4^{\circ} \mathrm{N} / 217.3^{\circ} \mathrm{E}\left(A_{95}=5.6^{\circ}, \mathrm{N}=11\right)$ for $\mathrm{A} 3$, and $\mathrm{D} / \mathrm{I}=10.9^{\circ} / 50.1^{\circ}\left(a_{95}=5.6^{\circ}, \mathrm{k}=38.6\right)$ and $\mathrm{VGP}=79.8^{\circ} \mathrm{N} /$ $242.4^{\circ} \mathrm{E}\left(A_{95}=5.0^{\circ}, \mathrm{N}=18\right)$ for $\mathrm{A} 4$. Our best estimates of the paleopoles for $\mathrm{A} 1, \mathrm{~A} 3$, and $\mathrm{A} 4$ are in remarkable agreement with the reference apparent polar wander path of China in late Cretaceous to early Paleogene, confirming that Korea has been rigidly attached to China (by implication to Eurasia) at least since the Cretaceous. The compiled paleomagnetic data of the Korean Peninsula suggest that the mode of clockwise rotations weakened since the mid-Jurassic. Such interesting variation of vertical rotations in the Korean Peninsula might result from the strike-slip motions of major faults developed in East Asia (the Tancheng-Lujiang fault to the northwest and the Korea-Taiwan strait fault to the southeast), near-field tectonic forcing of the subducting Pacific Plate beneath the Eurasian Plate, and far-field expressions of the India-Asia collision.
\end{abstract}

\section{Background}

East Asia is one of the world's poorly determined regions for reconstruction of Pangea (Besse and Courtillot 1991, 2002; Yang and Besse 2001; Enkin et al. 1992; Ma et al. 1993; Gilder et al. 2008; Pei et al. 2011). A robust reconstruction of Laurasia is possible only when Mesozoic paleogeography of the Korean Peninsula is well established, bridging the two sides of the Chinese cratons (e.g., Lee et al. 1987; Kim and Van der Voo 1990; Zhao et al. 1994, 1999; Doh et al. 1999, 2002; Park et al. 2003, 2005, 2007; Kim et al. 2009). The primary goal of paleomagnetism is to uncover information about the history of deformation and vertical rotations in geologic units. The present study is intended to analyze the variations in vertical axis block rotations in the Korean Peninsula with respect to more stable Chinese cratons.

\footnotetext{
* Correspondence: yongjaeyu@cnu.ac.kr

${ }^{1}$ Department of Geology and Earth Environmental Sciences, Chungnam

National University, 99 Daehak-ro, Daejeon 305-764, Korea

Full list of author information is available at the end of the article
}

The Korean Peninsula is located at the eastern end of the Eurasian Plate (Figure 1, inset), bounded by two major NNE-striking sinistral strike-slip fault systems of the Tancheng-Lujiang (Tan-Lu in abbreviation) fault to the northwest and the Korea-Taiwan strait fault to the southeast (Figure 1, inset). In particular, the Tan-Lu fault starts at eastern China and stretches north side of the Sino-Korean block over a distance of 1,000 km (Figure 1, inset). The southern part of the Korean Peninsula has five main tectonic units of Gyeonggi massif (GM), Ogcheon fold belt (OB), Ryongnam massif (RM), Gyeongsang Basin (GB), and Pohang Basin (PB) (e.g., Cluzel et al. 1991) (Figure 1). On the basis of combined paleomagnetic and paleontological analyses, it has been suggested that most tectonic units in Korea may have an affinity with South China while RM may have an affinity with North China (e.g., Kobayashi 1966, 1967; Doh and Piper 1994; Lee et al. 1996; Uno 1999; Uno and Chang 2000; Doh et al. 2002; Uno et al. 2004). 


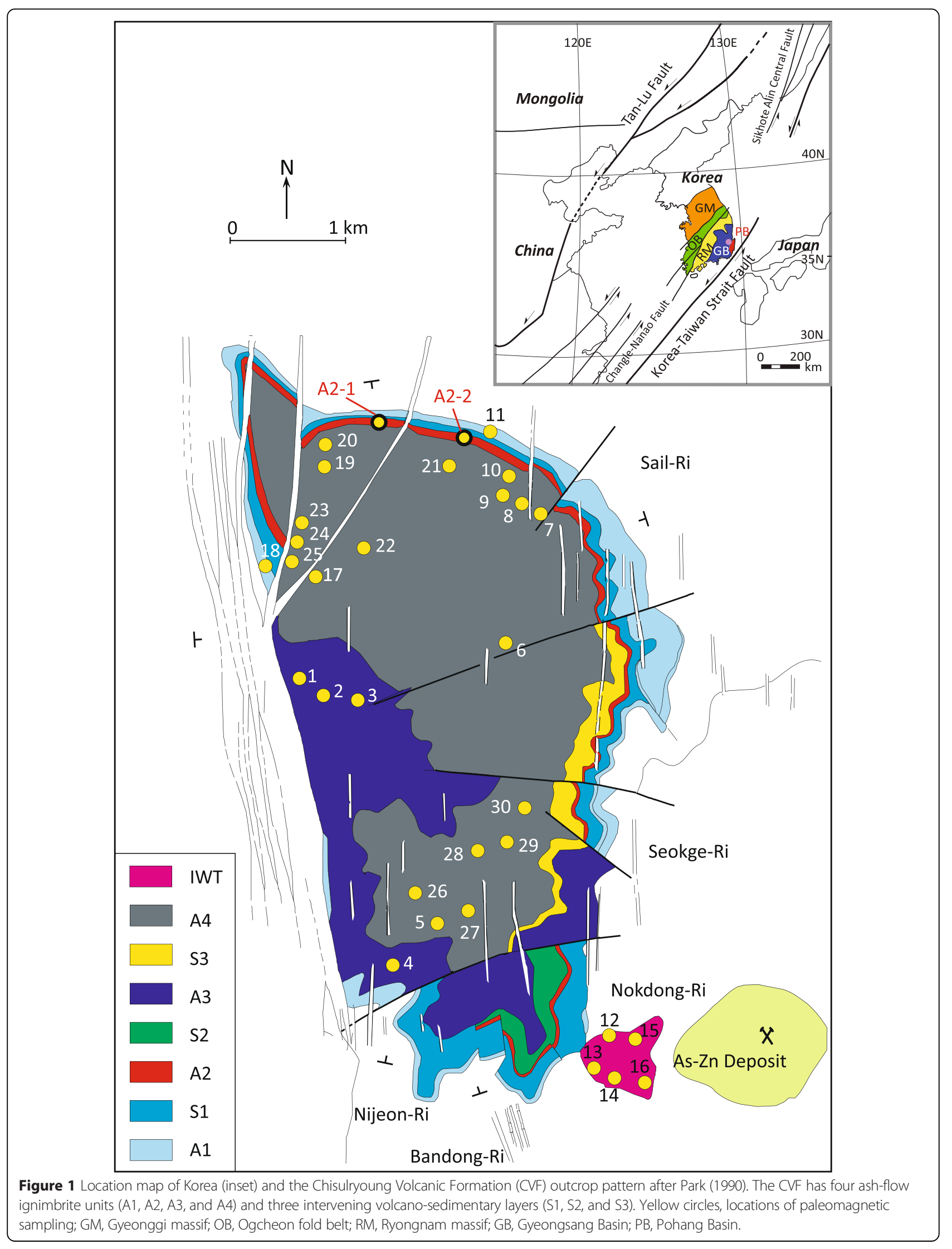


The present study deals with the paleomagnetism of late Cretaceous volcanic rocks in GB (Figure 1). Located in the southeastern part of the Korean Peninsula, GB is the largest non-marine sedimentary basin in the SinoKorean block. Paleomagnetic investigation of $\mathrm{GB}$ is necessary to enhance our understanding of the Mesozoic tectonic evolution of the Sino-Korean block. In the present study, we report paleomagnetic data along with high-precision zircon $\mathrm{U}-\mathrm{Pb}$ dating from the Chisulryoung Volcanic Formation (CVF) in GB, which can shed some light on the late Cretaceous tectonism in Korea, as well as possible tectonic correlation with the Eurasian Plate.

\section{Methods}

\section{Geology}

The CVF of southeastern Korea forms an extrusive outlier $(6 \times 3 \mathrm{~km})$ around Chisulryoung Mountain $(765 \mathrm{~m})$ (pink circle in Figure 1 inset). According to Reedman et al. (1987), the CVF was formed by two sequential cycles of subaerial explosive silicic volcanic activities in which an emplacement of thick ash-flows intercalated with volcanoclastic sedimentary rocks. It is typically a basin, circular in form whose underlying sedimentary rocks inclined with centripetal dips (Figure 1). Overall, the CVF lies within a broad structural basin regarded as a down sag caldera (Reedman et al. 1989).
The CVF comprises mainly densely to weakly welded acidic ash-flow tuffs which have been divided into four members (A1, A2, A3, and A4) and three intervening volcano-sedimentary members (S1, S2, and S3) according to their crystal content, grain-size distribution of pyroclastic material, and degree of consolidation and welding (Park and Kim 1985a, b; Park 1990) (Figure 2). As a first major eruption cycle, a sequence of lower members (A1, S1, A2, S2, and A3) predates the intrusion of the Cheogwari granodiorite whose hornblende $\mathrm{K}$-Ar age is $76.3 \pm 11.7 \mathrm{Ma}$ (Reedman et al. 1989). The A4 member is a product of the second eruption cycle, and the S3 member represents sedimentations that occurred between the two major eruption cycles (Reedman et al. 1989; Park 1990). To put it differently, the two major eruption cycles were separated by the intrusion of the Cheogwari granodiorite (Reedman et al. 1989). In particular, the A4 member comprises approximately 100 to $120 \mathrm{~m}$ of loosely welded pumice-rich tuff (A4a) overlain by about 80 to $120 \mathrm{~m}$ of densely welded high-density lithic-rich tuff (A4b) (Figure 2). The second eruptive cycle was terminated with the intrusion of the Gadaeri granite whose biotite K-Ar age is $63.9 \pm 1.8 \mathrm{Ma}$ (Reedman et al. 1989) (Figure 2). An intrusive welded tuff (IWT) plug, with an elliptical cross section $(700 \times 400 \mathrm{~m})$, has a eutaxitic texture nearly parallel to its subvertical contacts.

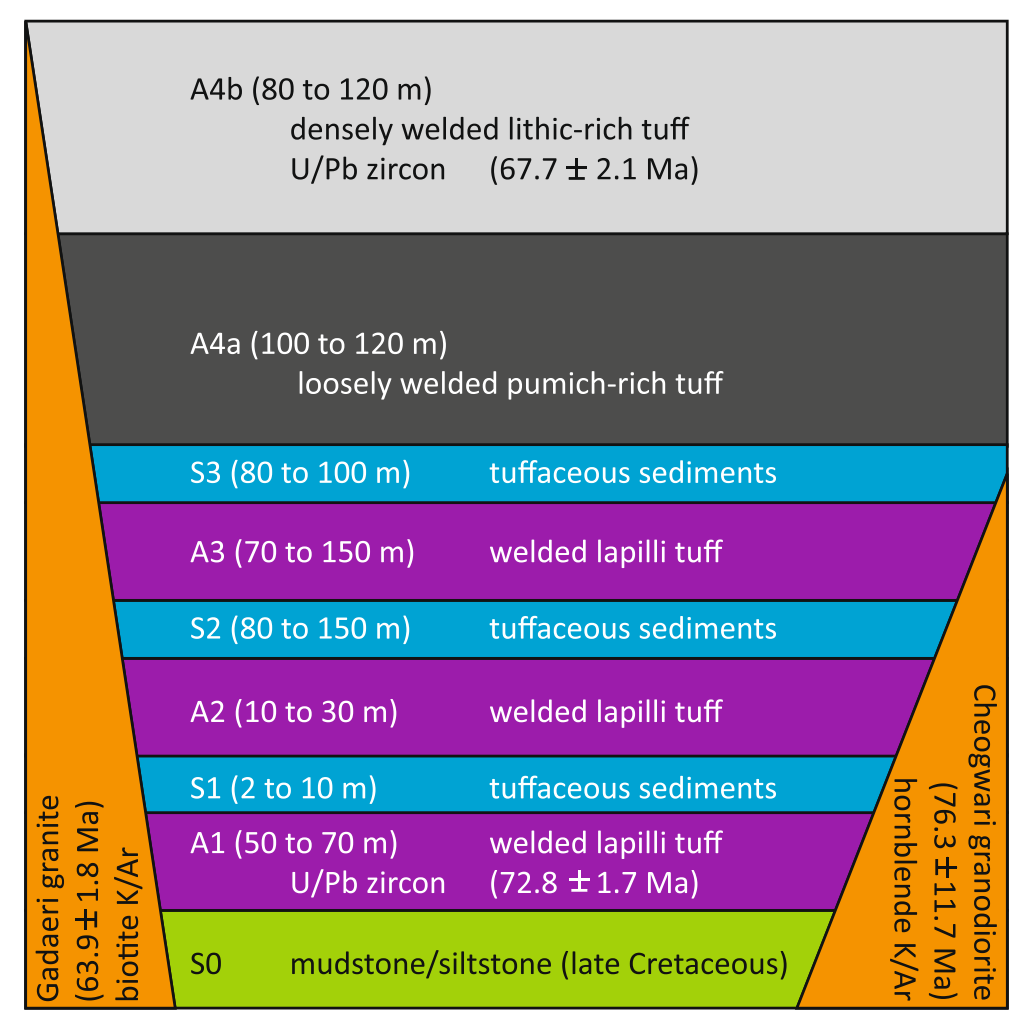

Figure 2 Schematic section illustrating relative stratigraphic positions of the CVF, lithologies, tentative thickness, and available age determinations. 
The IWT cuts; hence, it post-dates the Cheogwari granodiorite. Indeed, the IWT yielded sericite K-Ar age of $65.1 \pm 1.8 \mathrm{Ma}$, slightly older than the emplacement age of the Gadaeri granite (Reedman et al. 1987, 1989; Park 1990).

\section{Sampling and laboratory procedures}

Rheomorphic ash-flow tuffs occur as hot lateral flows invade the pumice deposits, producing extreme flattening and stretching of dense ignimbrites. Whenever possible, we avoided rheomorphic ignimbrites as they might compromise reliable remanence record. Fifty-four oriented samples were taken from six sites by in situ drilling. These sites are distributed in the western part of the study area where slopes are relatively gentle. In 24 sites where drilling was inapplicable due to high topography and steep slopes along the mountain side, oriented block samples were collected. Six to ten $2.5-\mathrm{cm}$ cylindrical specimens of each sample were alternating-field (AF) demagnetized in 12 steps to $90 \mathrm{mT}$ using a Molspin AF demagnetizer (ASC Scientific, Carlsbad, CA, USA). In addition, other specimens were thermally demagnetized, usually in $50^{\circ} \mathrm{C}$ steps to $500^{\circ} \mathrm{C}$ and then in smaller steps to $700^{\circ} \mathrm{C}$ using a non-inductive thermal demagnetizer (ASC Scientific Model TD-48, ASC Scientific, Carlsbad, CA, USA). Optimum demagnetization step to calculate a mean remanence direction was defined as that producing the minimum dispersion in direction. Sample storage, demagnetization, and spinner magnetometer measurements were performed in a magnetically shielded space with a nominal ambient field of $<200 \mathrm{nT}$ at the Paleomagnetism Laboratory, Korea University.

To date, the relative age sequence of the CVF was indirectly established on the basis of the K-Ar ages determined from the intervening intrusive granitoids (Figure 2). In an attempt to directly determine the age of the pyroclastic units, high-precision age dating was carried out. At first, zircons from the A1, A4, and IWT were dated by the U-Pb method using the Sensitive High Resolution Ion MicroProbe (SHRIMP) at the Korea Basic Science Institute. Details of operation and data reduction protocols were similar to those described by Yi et al. (2012). Zircons were extracted from crushed and pulverized samples, using standard magnetic and density separation. Cathodoluminescence (CL) and backscattered electron images were obtained using a scanning electron microscope (SEM) of JEOL 6610LV (JEOL Ltd., Akishima-shi, Japan). Zircon inclusions were identified by using an INCA $\mathrm{x}$-act energy-dispersive spectrometer (Oxford Instruments, Abingdon, UK). Concentrations of U and Th were calculated with reference to SL13 ( $\mathrm{U}=238$ $\mathrm{ppm}$ ). The measured ratio of ${ }^{206} \mathrm{~Pb} /{ }^{238} \mathrm{U}$ was calibrated for the standard of 1.1-Gyr-old FC1 zircon (Paces and Miller
1993). Concordia diagrams and age determination were made after excluding the outliers on the basis of the $t$-test using two commonly used programs of Squid 2.50 and Isoplot 3.71 (Ludwig 2008, 2009). Second, high-precision ${ }^{40} \mathrm{Ar} /{ }^{39} \mathrm{Ar}$ step-heating analyses were performed at the Argon Geochronology Laboratory, Oregon State University using the freshest matrix crushed from rock samples.

Seven zircon grains of A1 member yielded concordant $\mathrm{U}-\mathrm{Pb}$ ages of $72.8 \pm 1.7 \mathrm{Ma}$ with a mean square of the weighted deviates (MSWD) of 0.93 (Figure 3a). Similarly, eight zircon grains of A4 member displayed concordant U-Pb ages of $67.7 \pm 2.1$ Ma with a MSWD (York 1969) of 1.80 (Figure 3b). However, we failed to obtain reliable concordant $\mathrm{U}-\mathrm{Pb}$ ages from the IWT because of enormously high concentrations of uranium. We were also unable to retrieve scientifically meaningful ${ }^{40} \mathrm{Ar} /{ }^{39} \mathrm{Ar}$ ages for the rocks in the CVF. For instance, both stepheating plateau age spectra (Figure 3c) and inverse isochron regression fittings (Figure 3d) are all unacceptable with overestimated errors. Despite limited success, $\mathrm{U}-\mathrm{Pb}$ zircon ages of A1 $(72.8 \pm 1.7 \mathrm{Ma})$ and A4 (67.7 \pm $2.1 \mathrm{Ma}$ ) confirm that the two major eruption cycles of the CVF were separated by the intrusion of the Cheogwari granodiorite (hornblende K-Ar age of $76.3 \pm 11.7$ $\mathrm{Ma}$ ) and the magmatic activity of the CVF was terminated with the intrusion of the Gadaeri granite (biotite K-Ar age of $63.9 \pm 1.8 \mathrm{Ma}$ ).

\section{Results}

Hysteresis loops were measured from 44 rock chips on an alternating gradient force magnetometer at the University of Toronto, Canada. Values of saturation magnetization $\left(M_{s}\right)$, saturation remanence $\left(M_{r}\right)$, and coercive force $\left(B_{c}\right)$ were determined from hysteresis loops. Hysteresis parameters were determined after appropriate paramagnetic slope correction. Representative hysteresis loops are given in Figure 4. In most samples, hysteresis loops for fineto coarse-grained magnetite are typically observed (Figure 4a,b). For example, sample A4-30-4 shows a high remanence ratio $\left(M_{r} / M_{s}\right)$ of $\approx 0.4$, similar to near single-domain (SD) or fine pseudo-single-domain (PSD) characteristics (Figure 4a). On the other hand, A4-17-5 shows more multidomain (MD)-like behavior of low remanence ratio of $\approx 0.2$ (Figure $4 \mathrm{~b}$ ). High coercivities over $100 \mathrm{mT}$ and high remanence ratio over 0.5 from the four chips of site 27 suggest the presence of highly coercive mineral other than magnetite (Figure 4c). In a Néel (1955) plot of remanence ratio $\left(M_{r} / M_{s}\right)$ versus coercivity $\left(B_{c}\right)$, a total of 40 representative magnetite-containing chips follow the trend of the SD-MD mixing lines (Figure 4d) according to the criteria of Tauxe et al. (2002).

Demagnetization results were displayed in geographic coordinates in terms of total intensity variation of magnetization, equal-area stereographic plot, and vector 

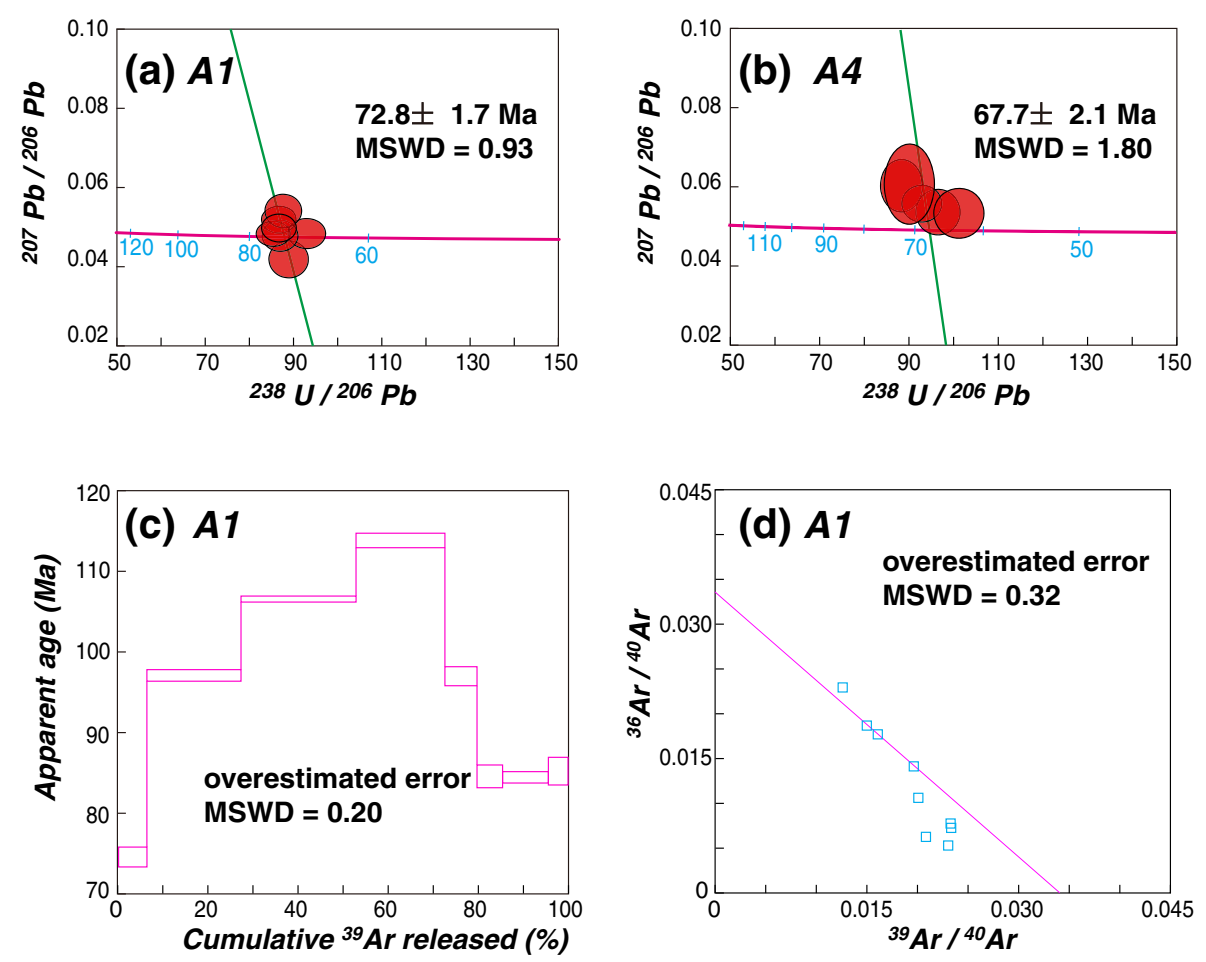

Figure 3 Ages of CVF. (a) U/Pb concordia diagrams for zircon from A1. (b) U/Pb concordia diagrams for zircon from A4. Error ellipses are at $1 \sigma$ level, and the calculated ages are at 95\% confidence. (c) Age spectra of step-heating Ar-Ar analysis from A1. (d) Inverse isochrons of Ar-Ar age determination from A1. Note that Ar-Ar determination showed overestimated errors where MSWD represents the mean square of the weighted deviates (York 1969).

projections using a commonly used PuffinPlot (Lurcock and Wilson 2012). The characteristic remanent magnetization (ChRM) directions were calculated from a principal component analysis (Kirschvink 1980). Virtual geomagnetic poles (VGPs) were calculated for each site, and mean paleomagnetic poles and their associated confidence limits were accordingly defined. Directions of natural remanent magnetization (NRM) prior to demagnetization treatments were slightly dispersed for each site, suggesting a weak viscous magnetic overprint. Magnetically weak samples yielded either an aberrant direction or a direction that progressively approaches the characteristic direction but fails to achieve a stable end point. These aberrant samples (see Table 1) were not used in mean calculation. In a few sites, a great circle method (McFadden and McElhinny 1988) was applied in mean calculation whenever NRM directions follow a great circle demagnetization trajectory.

\section{The first eruptive cycle (A1, A2, and A3)}

Forty-six oriented samples were collected at six sites from the first eruptive cycle: two (sites 11 and 18) in A1 and four (sites 1, 2, 3, and 4) in A3 (Figures 1 and 2). A weak spurious magnetization is removed usually $<10$ $\mathrm{mT}$ or $150^{\circ} \mathrm{C}$, after which a stable ChRM is identified from 10 to $90 \mathrm{mT}$ (Figure $5 \mathrm{a}$ ) or $100^{\circ} \mathrm{C}$ to $580^{\circ} \mathrm{C}$ (Figure $5 \mathrm{~b}$ ). The maximum unblocking temperature of $580^{\circ} \mathrm{C}$ reveals magnetite as a main remanence carrier (Figure 5b). The stable components are uniformly of normal polarity both for A1 and A3 (Figure 5, Table 1).

In A3, one of the four sites (site 4) has anomalous but well-clustered directions (Table 1). It is unclear whether site 4 records an isolated yet unidentified block movement or a short-lived geomagnetic polarity excursion. Nonetheless, we discarded the results of site 4 in mean calculation (Table 1). Site mean directions and corresponding paleopoles are $D / I=19.1^{\circ} / 49.2^{\circ}\left(\alpha_{95}=\right.$ $\left.4.2^{\circ}, k=76.5\right)$ and VGP $=73.1^{\circ} \mathrm{N} / 232.1^{\circ} \mathrm{E}\left(A_{95}=3.7^{\circ}\right.$, $N=3$ ) for A3.

The mean results for $\mathrm{A} 1$ were based on two sites $(N=2$; sites 11 and 18). As the Fisher site mean determinations require at least three (i.e., $N \geq 3$ ) individual paleomagnetic mean directions, we used combined specimen mean directions $(N=11 ; N=4$ for site 11 and $N=7$ for site 18). Combined mean directions and corresponding paleopoles are $D / I=24.9^{\circ} / 52.9^{\circ}\left(\alpha_{95}=5.9^{\circ}, k=61.7\right)$ and VGP $=69.4^{\circ}$ $\mathrm{N} / 217.3^{\circ} \mathrm{E}\left(A_{95}=5.6^{\circ}, N=11\right)$ for A3 (Table 1$)$.

For A2, 14 samples were collected at two sites (A2-1 and A2-2 in Figure 1). Unfortunately, all the samples were weakly magnetized and become fractured during 

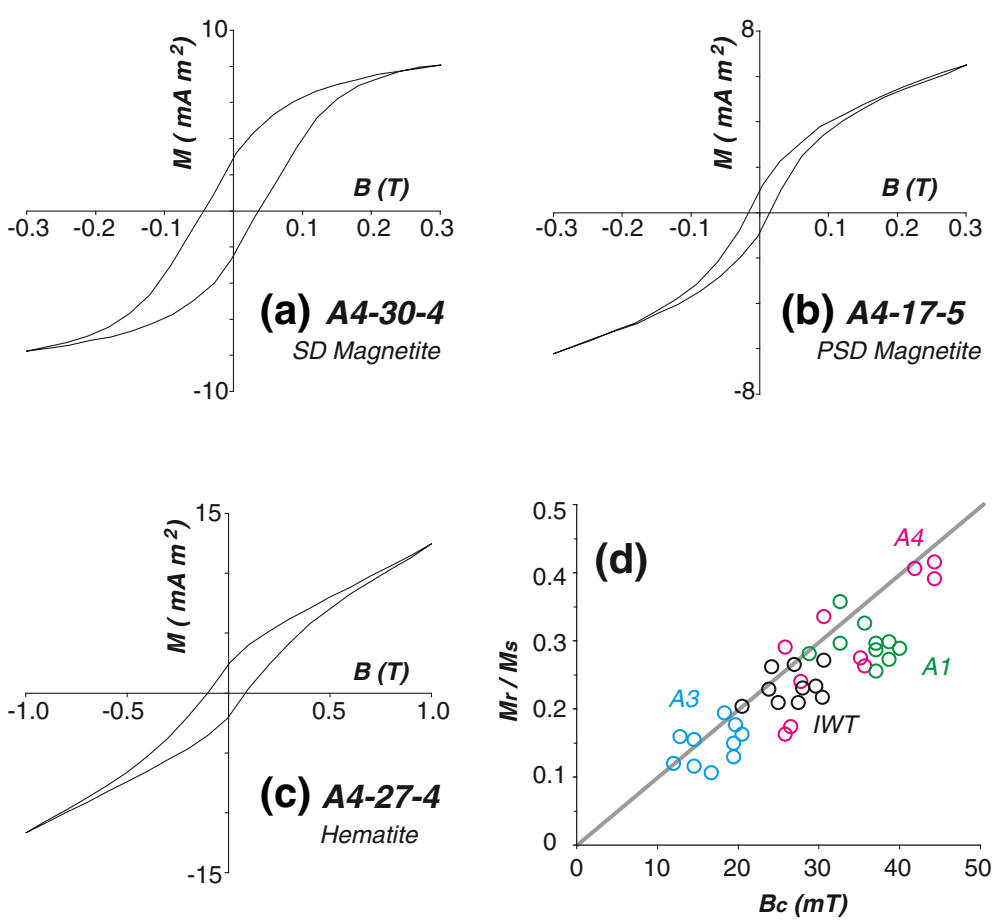

Figure 4 Hysteresis loops and hysteresis results displayed in a Néel (1955) plot. Hysteresis loops for (a) A4-30-4, (b) A4-17-5, and (c) A4-27-4. (d) Hysteresis results displayed in a Néel (1955) plot of remanence ratio $\left(M_{r} / M_{s}\right)$ versus coercivity $\left(B_{c}\right)$, enveloping a typical trend of the single domain (SD)-multidomain (MD) mixing lines.

thermal demagnetization. Hence, we were unable to retrieve reliable paleomagnetic results from A2.

\section{Intrusive welded tuff}

Forty-four oriented samples were collected at five sites (sites 12, 13, 14, 15, and 16) from the IWT. All the samples exhibited stable demagnetization behavior (Figure 6). During AF demagnetization, the median destructive field (MDF) was over 30 to $40 \mathrm{mT}$ (Figure 6a). Thermal demagnetization data show narrow unblocking temperature spectra of $500^{\circ} \mathrm{C}$ to $600^{\circ} \mathrm{C}$, consistent with a fine-grained magnetite as the principal carrier of magnetic remanence (Figure 6b). Paleomagnetic mean directions and paleopoles for IWT are $D / I=285.7^{\circ} / 82.3^{\circ}\left(\alpha_{95}=5.3^{\circ}, k=17.6\right)$ and VGP $=$ $38.1^{\circ} \mathrm{N} / 110.5^{\circ} \mathrm{E}\left(A_{95}=10.1^{\circ}, N=5\right)$ (Table 2$)$.

Paleomagnetic data from the IWT showed high magnetic inclination and radially scattered magnetic declination (Table 2). Rheomorphic ash-flow tuffs develop preferred alignment of pyroclasts that occurred shortly after the emplacement of laminar viscous flow (Wolff and Wright 1981). Then, it is likely that high magnetic inclination of IWT results from rheomorphism (Uno et al. 2013).

Table 1 Paleomagnetic results in the first eruption cycle

\begin{tabular}{|c|c|c|c|c|c|c|c|c|c|c|c|c|}
\hline Member & Site & $\varphi_{s}$ & $\lambda_{s}$ & $n_{1} / n_{2}$ & $D_{i}$ & $I_{i}$ & $k$ & $a_{95}$ & $\varphi_{p}$ & $\lambda_{p}$ & $d p$ & $d m$ \\
\hline \multirow[t]{5}{*}{$\overline{\mathrm{A} 3}$} & 1 & 129.14 & 35.40 & $6 / 10$ & 16.2 & 48.0 & 87.8 & 7.2 & 239.2 & 74.9 & 6.2 & 9.4 \\
\hline & 2 & 129.14 & 35.40 & $5 / 7$ & 13.8 & 49.3 & 59.6 & 10.0 & 239.5 & 77.3 & 8.8 & 13.3 \\
\hline & 3 & 129.14 & 35.40 & $5 / 7$ & 23.2 & 50.3 & 65.4 & 9.5 & 225.2 & 70.2 & 8.5 & 12.7 \\
\hline & $4^{\mathrm{a}}$ & 129.14 & 35.39 & $9 / 9$ & 134.7 & 15.0 & 28.9 & 9.7 & 183.1 & -29.4 & 5.1 & 10.0 \\
\hline & Mean & & & & 19.1 & 49.2 & 76.5 & 4.2 & 232.1 & 73.1 & $A_{95}=$ & 3.7 \\
\hline \multirow[t]{3}{*}{$\mathrm{A} 1$} & 11 & 129.15 & 35.41 & $4 / 8$ & 16.6 & 52.2 & 82.2 & 10.2 & 225.1 & 76.0 & 9.6 & 14.0 \\
\hline & 18 & 129.14 & 35.41 & $7 / 11$ & 29.8 & 53.1 & 59.7 & 7.9 & 214.5 & 65.5 & 7.6 & 11.0 \\
\hline & Mean & & & & 24.9 & 52.9 & 61.7 & 5.9 & 217.3 & 69.4 & $A_{95}=$ & 5.6 \\
\hline
\end{tabular}

$\varphi_{p} / \lambda_{p}$, sampling site longitude/latitude; $n_{1} / n_{2}$, number of samples used in calculating means/demagnetized at each site; $D_{i} / l_{i}$, mean declination/inclination; $k$, precision parameter; $a_{95}, 95 \%$ confidence limit; $\varphi_{p} / \lambda_{p}$, VGP longitude/latitude; $d p / d m$, confidence limits; $A_{95}$, the angular radius of an ellipse within which the mean pole lies within $95 \%$ confidence. ${ }^{a}$ Not included in mean calculation. 


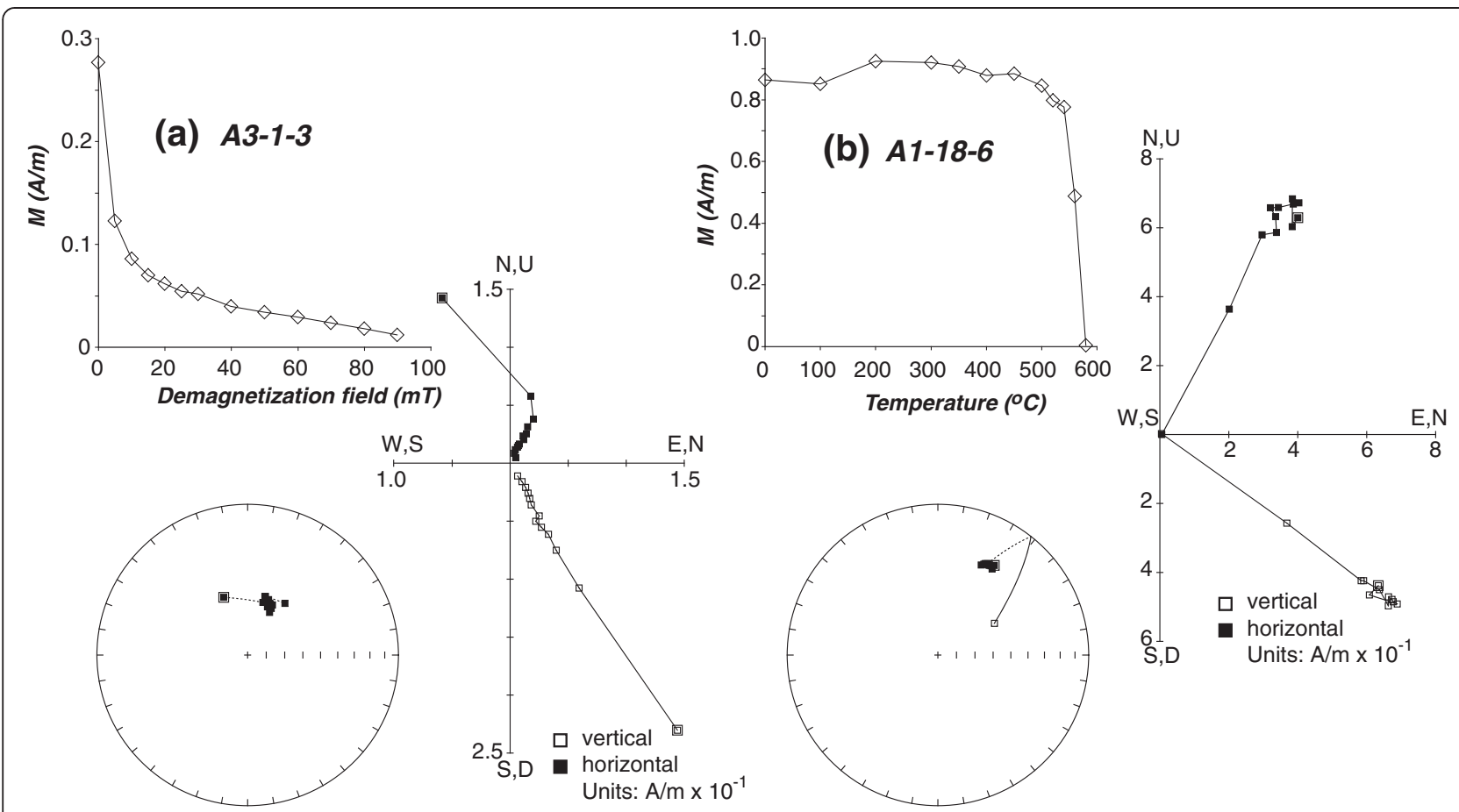

Figure 5 Alternating-field (AF) and thermal demagnetization results for (a) A3-1-3 and (b) A1-18-6. Total intensity variation of magnetization, equal-angle stereographic plot, and vector projections in geographic coordinates. In vector plots, open and solid squares represent vertical and horizontal plane projections, respectively, using a PuffinPlot (Lurcock and Wilson 2012).

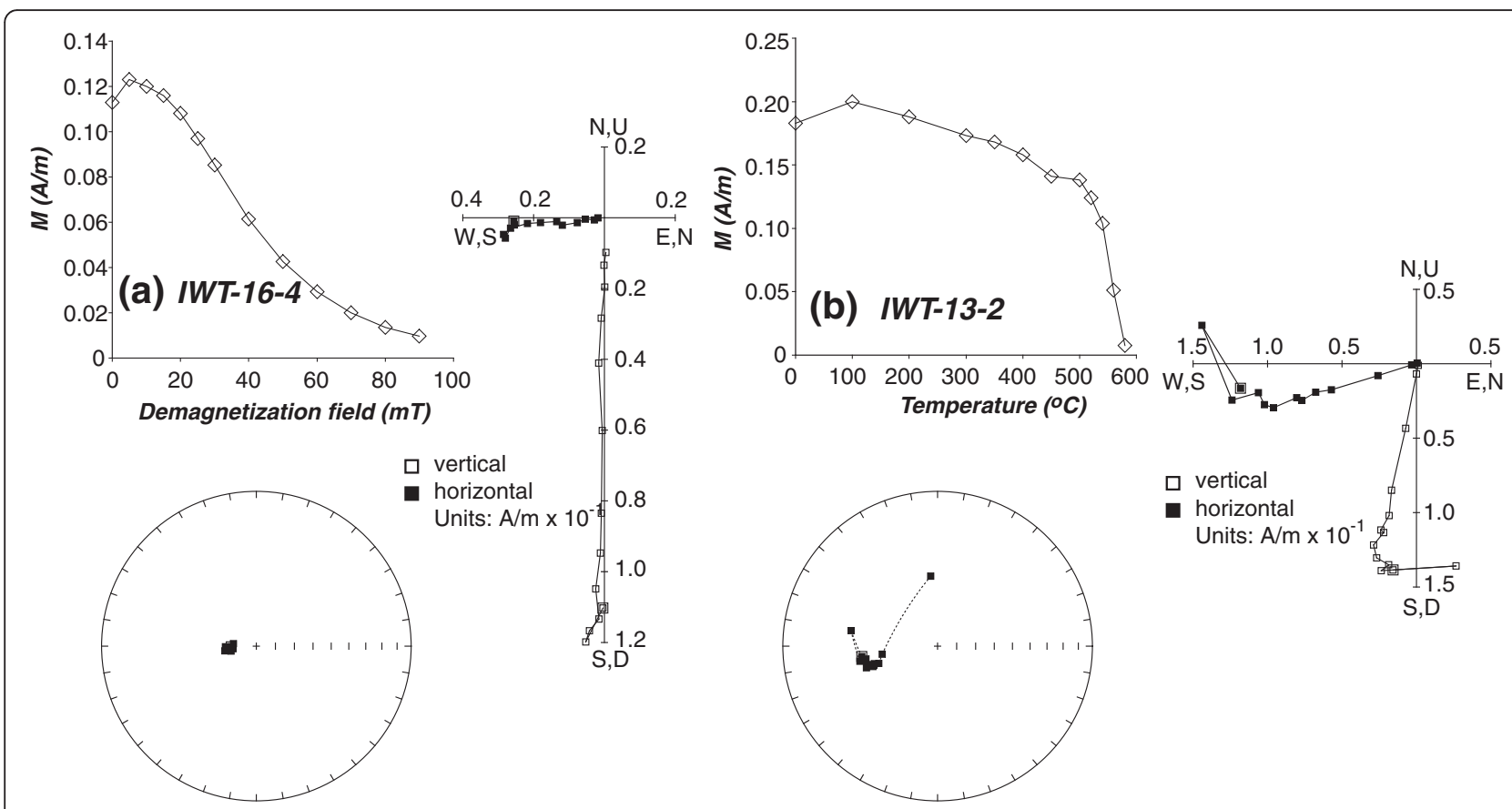

Figure 6 Alternating-field (AF) and thermal demagnetization results for (a) IWT 16-4 and (b) IWT 13-2. Total intensity variation of magnetization, equal-angle stereographic plot, and vector projections in geographic coordinates. In vector plots, open and solid squares represent vertical and horizontal plane projections, respectively, using a PuffinPlot (Lurcock and Wilson 2012). 
Table 2 Paleomagnetic results in the second eruption cycle

\begin{tabular}{|c|c|c|c|c|c|c|c|c|c|c|c|c|}
\hline Member & Site & $\varphi_{s}$ & $\lambda_{s}$ & $n_{1} / n_{2}$ & $D_{i}$ & $I_{i}$ & $K$ & $a_{95}$ & $\varphi_{p}$ & $\lambda_{p}$ & $d p$ & $d m$ \\
\hline \multirow[t]{22}{*}{ A4 } & $5^{a}$ & 129.15 & 35.40 & $4 / 6$ & 138.8 & -54.7 & 24.9 & 18.8 & 263.7 & -56.8 & 27.4 & 32.1 \\
\hline & 6 & 129.15 & 35.40 & $4 / 5$ & 17.5 & 13.7 & 27.1 & 18.0 & 275.6 & 57.3 & 9.4 & 18.4 \\
\hline & 7 & 129.15 & 35.41 & $6 / 7$ & 27.2 & 51.0 & 24.8 & 11.5 & 220.7 & 67.1 & 10.5 & 15.6 \\
\hline & 8 & 129.15 & 35.41 & $6 / 7$ & 36.5 & 33.0 & 60.5 & 8.7 & 237.8 & 53.3 & 5.6 & 9.9 \\
\hline & 9 & 129.15 & 35.41 & $5 / 6$ & 36.1 & 21.3 & 35.7 & 13.0 & 246.9 & 49.2 & 7.2 & 13.7 \\
\hline & 10 & 129.15 & 35.41 & $4 / 6$ & 20.5 & 23.4 & 24.4 & 19.0 & 265.4 & 60.3 & 10.8 & 20.2 \\
\hline & 17 & 129.14 & 35.41 & $11 / 11$ & 346.1 & 48.9 & 104.7 & 4.5 & 17.5 & 77.0 & 3.9 & 5.9 \\
\hline & 19 & 129.14 & 35.41 & $14 / 18$ & 346.2 & 36.5 & 15.5 & 10.4 & 351.6 & 70.6 & 7.1 & 12.1 \\
\hline & 20 & 129.14 & 35.41 & $17 / 23$ & 358.2 & 32.3 & 37.6 & 5.9 & 314.7 & 72.1 & 3.8 & 6.7 \\
\hline & 21 & 129.15 & 35.41 & $24 / 24$ & 16.4 & 36.2 & 36.0 & 5.0 & 261.5 & 69.0 & 3.4 & 5.8 \\
\hline & 22 & 129.14 & 35.41 & $14 / 14$ & 359.4 & 41.3 & 16.6 & 10.1 & 311.9 & 78.3 & 7.5 & 12.3 \\
\hline & 23 & 129.14 & 35.41 & $9 / 21$ & 201.3 & -41.6 & 12.2 & 15.4 & 65.3 & -68.3 & 11.5 & 18.8 \\
\hline & 24 & 129.14 & 35.41 & $10 / 16$ & 192.2 & -53.0 & 8.3 & 17.8 & 46.0 & -79.8 & 17.1 & 24.7 \\
\hline & 25 & 129.14 & 35.41 & $10 / 13$ & 357.0 & 48.4 & 25.5 & 9.8 & 332.8 & 83.5 & 8.4 & 12.9 \\
\hline & 26 & 129.15 & 35.39 & $13 / 14$ & 186.6 & -46.9 & 10.2 & 13.7 & 89.7 & -80.8 & 11.4 & 17.7 \\
\hline & 27 & 129.15 & 35.39 & $19 / 22$ & 192.2 & -55.3 & 15.4 & 8.8 & 33.0 & -80.1 & 8.9 & 12.5 \\
\hline & 28 & 129.15 & 35.39 & $14 / 14$ & 11.1 & 60.7 & 22.1 & 8.6 & 180.0 & 79.3 & 10.0 & 13.1 \\
\hline & 29 & 129.15 & 35.39 & $8 / 10$ & 3.9 & 32.3 & 23.5 & 11.7 & 297.2 & 71.8 & 7.4 & 13.2 \\
\hline & 30 & 129.15 & 35.40 & $17 / 19$ & 2.7 & 30.9 & 30.3 & 6.6 & 301.1 & 71.1 & 4.1 & 7.4 \\
\hline & Mean & Normal & & & 10.7 & 50.0 & 31.1 & 7.2 & 243.4 & 79.9 & $A_{95}=$ & 6.4 \\
\hline & Mean & Reversed & & & 192.3 & -39.7 & 112.7 & 8.7 & 266.0 & -73.3 & $A_{95}=$ & 6.3 \\
\hline & Mean & & & & 10.9 & 50.1 & 38.6 & 5.6 & 242.4 & 79.8 & $A_{95}=$ & 5.0 \\
\hline \multirow[t]{6}{*}{ IWT } & 12 & 129.16 & 35.39 & 9/9 & 99.9 & 84.2 & 56.3 & 6.9 & 142.6 & 32.7 & 13.4 & 13.6 \\
\hline & 13 & 129.16 & 35.39 & $10 / 10$ & 240.4 & 70.6 & 12.7 & 14.1 & 98.1 & 14.0 & 21.2 & 24.4 \\
\hline & 14 & 129.16 & 35.38 & $10 / 10$ & 303.2 & 76.3 & 27.5 & 9.4 & 97.5 & 45.7 & 16.1 & 17.4 \\
\hline & 15 & 129.16 & 35.38 & $8 / 8$ & 338.4 & 73.8 & 22.6 & 11.9 & 106.1 & 61.8 & 19.3 & 21.4 \\
\hline & 16 & 129.16 & 35.38 & $7 / 7$ & 265.5 & 83.0 & 47.9 & 8.8 & 112.7 & 33.2 & 16.8 & 17.2 \\
\hline & Mean & & & & 285.7 & 82.3 & 17.6 & 5.3 & 110.5 & 38.1 & $A_{95}=$ & 10.1 \\
\hline
\end{tabular}

$\varphi_{p} / \lambda_{p}$, sampling site longitude/latitude; $n_{1} / n_{2}$, number of samples used in calculating means/demagnetized at each site; $D_{i} / l_{i}$, mean declination/inclination; $k$, precision parameter; $a_{95}, 95 \%$ confidence limit; $\varphi_{p} / \lambda_{p}$, VGP longitude/latitude; $d p / d m$, confidence limits; $A_{95}$, the angular radius of an ellipse within which the mean pole lies within $95 \%$ confidence. ${ }^{\mathrm{a}}$ Not included in mean calculation.

\section{The second eruptive cycle (A4)}

A total of 242 oriented samples were collected at 19 sites (sites $5,6,7,8,9,10,17,19,20,21,22,23,24,25,26$, 27, 28, 29, and 30) from the second eruptive cycle. Progressive AF and thermal demagnetization isolated a well-defined stable magnetization (Figure 7). An initial plateau with relatively high MDF in AF demagnetization (Figure $7 \mathrm{a}$ ) and a sharp drop of magnetization near $580^{\circ}$ $\mathrm{C}$ in thermal demagnetization (Figure $7 \mathrm{~b}$ ) are characteristics of fine-grained magnetite.

A unique demagnetization behavior was observed from the seven samples in site 27 (Figure 8). These samples are completely resistant to AF demagnetization (Figure 8a) and have maximum unblocking temperatures approximately $680^{\circ} \mathrm{C}$ (Figure $8 \mathrm{~b}$ ), suggesting that the remanence is carried by hematite. The mean direction of these seven hematite-bearing samples is consistent with that of twelve other magnetite-bearing samples from the same sampling site in $95 \%$ confidence limits. It is difficult to envisage a low-temperature chemical process that would generate both magnetite and hematite. It is possible that a high-temperature deuteric oxidation formed both magnetite and hematite (e.g., Schlinger et al. 1991) during the early stage of emplacement. If so, the NRM in site 27 is a combination of thermoremanent magnetization (TRM) carried by magnetite and thermochemical remanent magnetization (TCRM) acquired during high-temperature oxidation of magnetite to hematite (e.g., May et al. 1986).

In $\mathrm{A} 4$, the ChRM directions show both normal and reversed polarities (Table 2). For instance, the ChRM directions of four sites (sites 23, 24, 26, and 27) are 


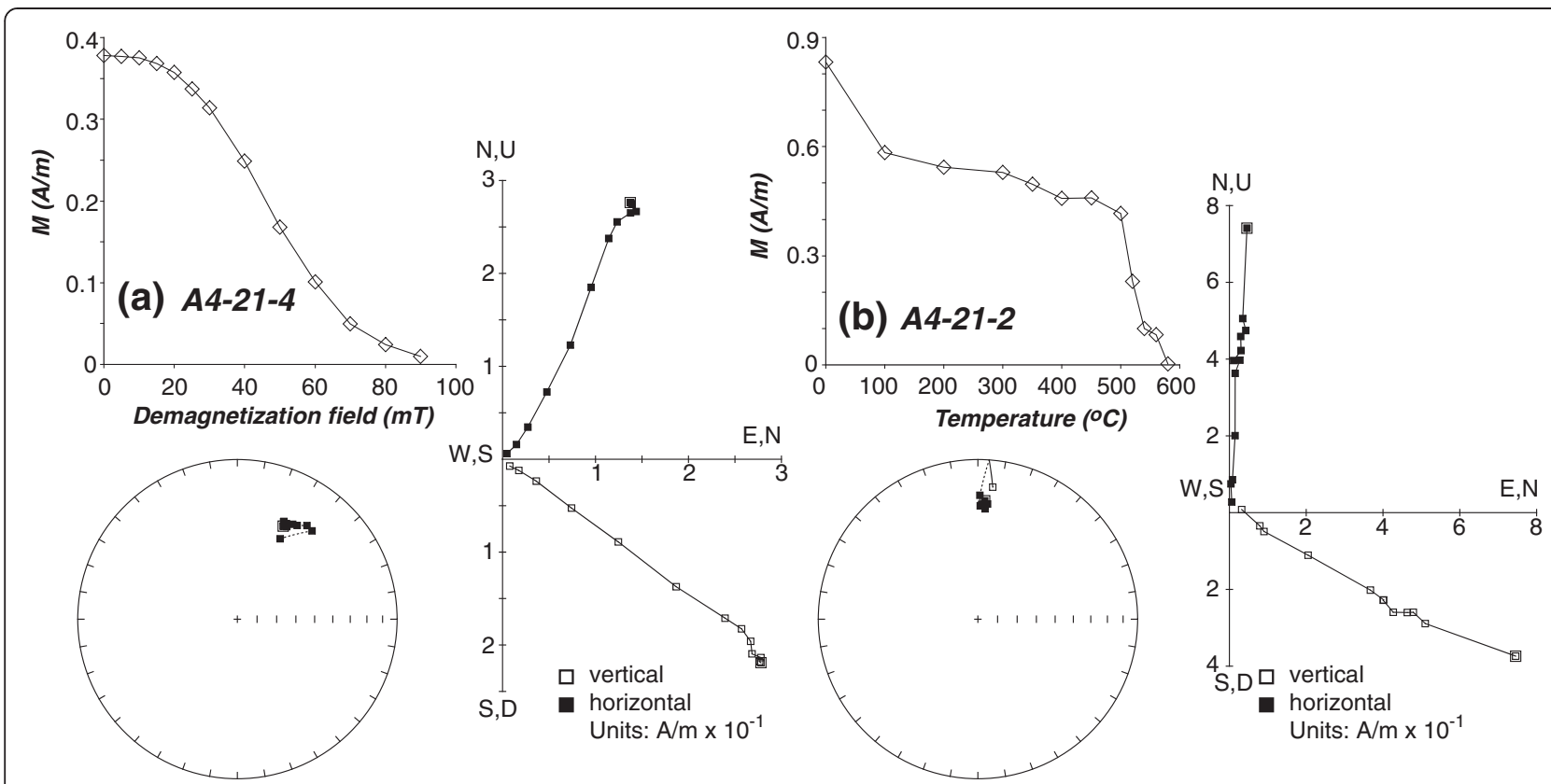

Figure 7 Alternating-field (AF) and thermal demagnetization results for (a) A4-21-4 and (b) A4-21-2. Total intensity variation of magnetization, equal-angle stereographic plot, and vector projections in geographic coordinates. In vector plots, open and solid squares represent vertical and horizontal plane projections, respectively, using a PuffinPlot (Lurcock and Wilson 2012).

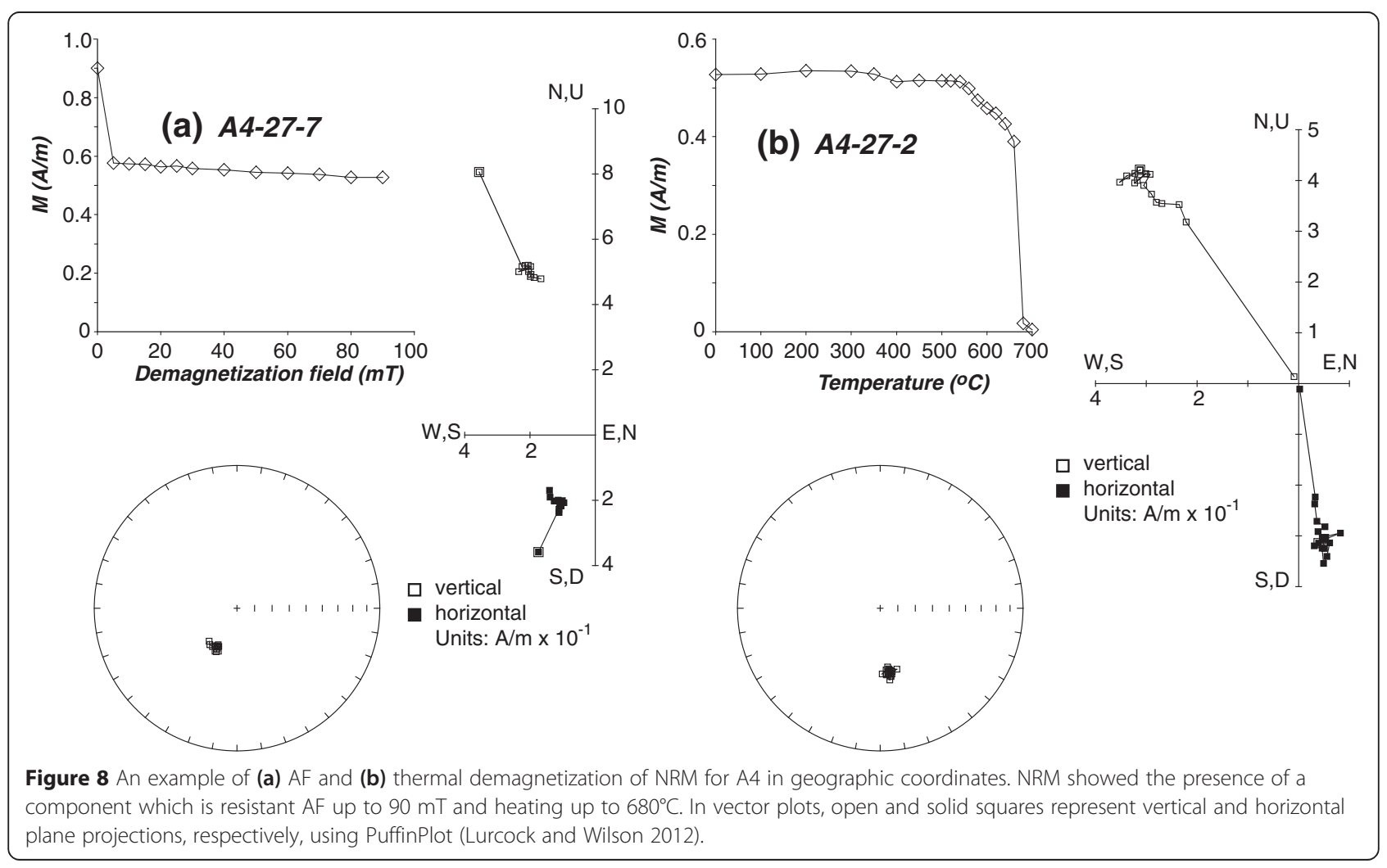


reversely magnetized, while those of fourteen sites (sites $6,7,8,9,10,17,19,20,21,22,25,28,29$, and 30) are normal (Table 2). Paleomagnetic site mean directions and paleopoles are $D / I=10.7^{\circ} / 50.0^{\circ}\left(\alpha_{95}=7.2^{\circ}, k=31.1\right)$ and VGP $=79.9^{\circ} \mathrm{N} / 243.4^{\circ} \mathrm{E}\left(A_{95}=6.4^{\circ}, N=14\right)$ for normal polarity and $D / I=192.3^{\circ} /-39.7^{\circ}\left(\alpha_{95}=8.7^{\circ}, k=112.7\right)$ and $\mathrm{VGP}=73.3^{\circ} \mathrm{S} / 266.0^{\circ} \mathrm{E}\left(A_{95}=6.3^{\circ}, N=4\right)$ for reversed polarity (Table 2). The mean ChRM directions from fourteen normal polarity sites are anti-parallel to those of four reversed polarity sites (Table 2). Indeed, the ChRM directions pass the reversal test for paleomagnetic stability (Figure 9). When combined, the paleomagnetic site mean direction and paleopole for the entire A4 are $D / I=10.9^{\circ} / 50.1^{\circ}\left(\alpha_{95}=5.6^{\circ}, k=38.6\right)$ and VGP $=$ $79.8^{\circ} \mathrm{N} / 242.4^{\circ} \mathrm{E}\left(A_{95}=5.0^{\circ}, N=18\right)$ (Table 2).

\section{Discussion}

High-precision $\mathrm{U}-\mathrm{Pb}$ zircon age obtained from the base of the CVF (i.e., A1) is $72.8 \pm 1.7 \mathrm{Ma}$ (Figures 2 and 3). $\mathrm{U}-\mathrm{Pb}$ zircon geochronology is unavailable for the overlying sequential tuff layers and tuffaceous sediments for the first eruption cycle. On the basis of normal polarities observed for both A1 and A3, the first eruption cycle of the CVF can be constrained as chron $32 \mathrm{~N}$ in late Campanian. On the other hand, U-Pb zircon age of $67.7 \pm$ 2.1 Ma was obtained from the stratigraphically higher A4 (Figure 2). While magnetite-bearing tuffs retained TRM of normal polarity, hematite-containing tuffs preserved TCRM of reversed polarity (Figure 8, Table 2). Existence of dual polarities in the same site implies that the second eruption cycle of the CVF may record polarity transition from chron C31N to C30R in late Maastrichitian. Overall, the CVF reflects late Cretaceous volcanism that definitely predates the Paleogene (Figure 2).

Paleomagnetic stability of pyroclastics is influenced by the structural correction to restore the beds to horizontal, degree of bedding tilts, and the caldera affinity. In the present study, no structural correction was employed in analyzing data. Determining systematic variation of attitudes of the intervening volcanic-sedimentary layers was unavailable because the horizontal continuity of A1, S1, A2, S2, A3, and S3 was poor. Instead, we relied on the between- or among-site directional consistency of paleomagnetic directions as a sideline evidence in assessing the quality of paleomagnetic directions. For instance, it is obvious that paleomagnetic mean direction is strongly influenced by the caldera affinity as IWT showed high inclination (Table 2). Therefore, the paleomagnetic mean direction of IWT was excluded in further tectonic discussion. On the other hand, results from A4 suggest that paleomagnetic directions were less relevant to the distances from sampling sites to volcanic-sedimentary boundaries or local faults (Tables 1 and 2).

Due to their inherent sporadic nature, pyroclastic rocks fossilize spot-readings of geomagnetic field vector during volcanic eruptions. As CVF does not reflect massive ever-lasting eruptions, it is difficult to imagine that secular variation is completely averaged out. However, the presence of dual polarities in flow A4 provides a strong rationale for the averaging out of secular variation (Figure 9).

The paleomagnetic poles of $\mathrm{A} 1, \mathrm{~A} 3$, and $\mathrm{A} 4$ show a counterclockwise swing in the third quadrant (Figure 10). The apparent polar wander path (APWP) of CVF covers almost $60^{\circ}$ swing of VGP longitude (from eastern Alaska to northern Greenland) but about $10^{\circ}$ increase of VGP latitude (Figure 10). VGP positions of A1 and A3 fell squarely well on the paleopoles of China in Cretaceous age (Gilder and Courtillot 1997; Huang et al. 2007). In particular, the paleopole of A3 is statistically identical to a recently refined late Cretaceous reference pole for the stable South China (Li et al. 2013). On the other hand, the paleopole of A4 is statistically indistinguishable to the paleopoles of China in early Tertiary (Zhao et al.

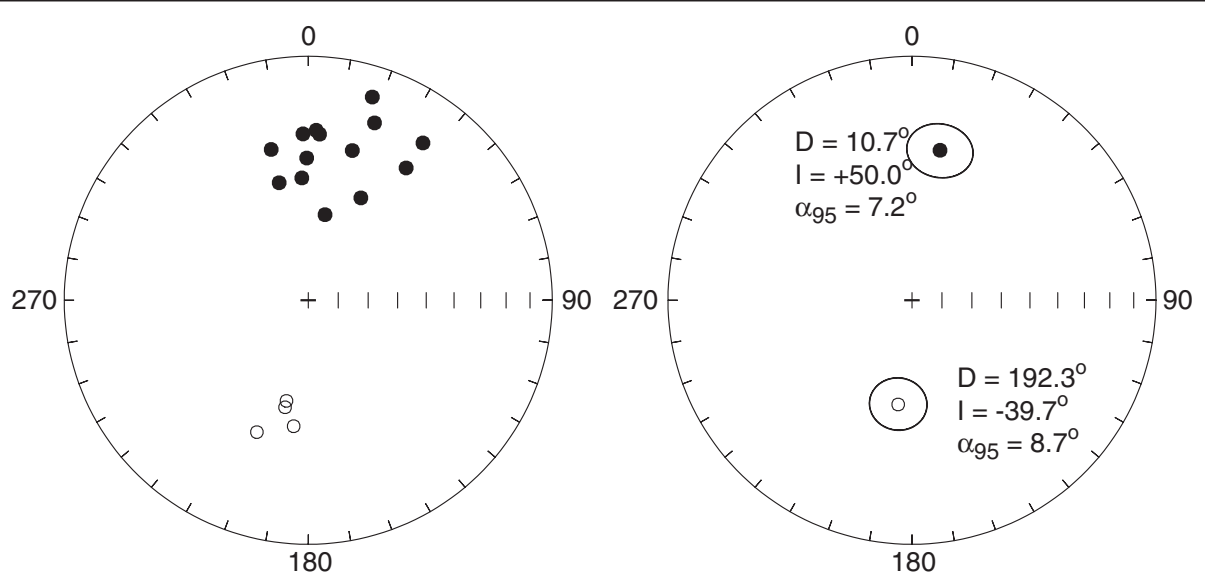

Figure 9 Paleomagnetic site mean directions of A4 pass the reversal test. 

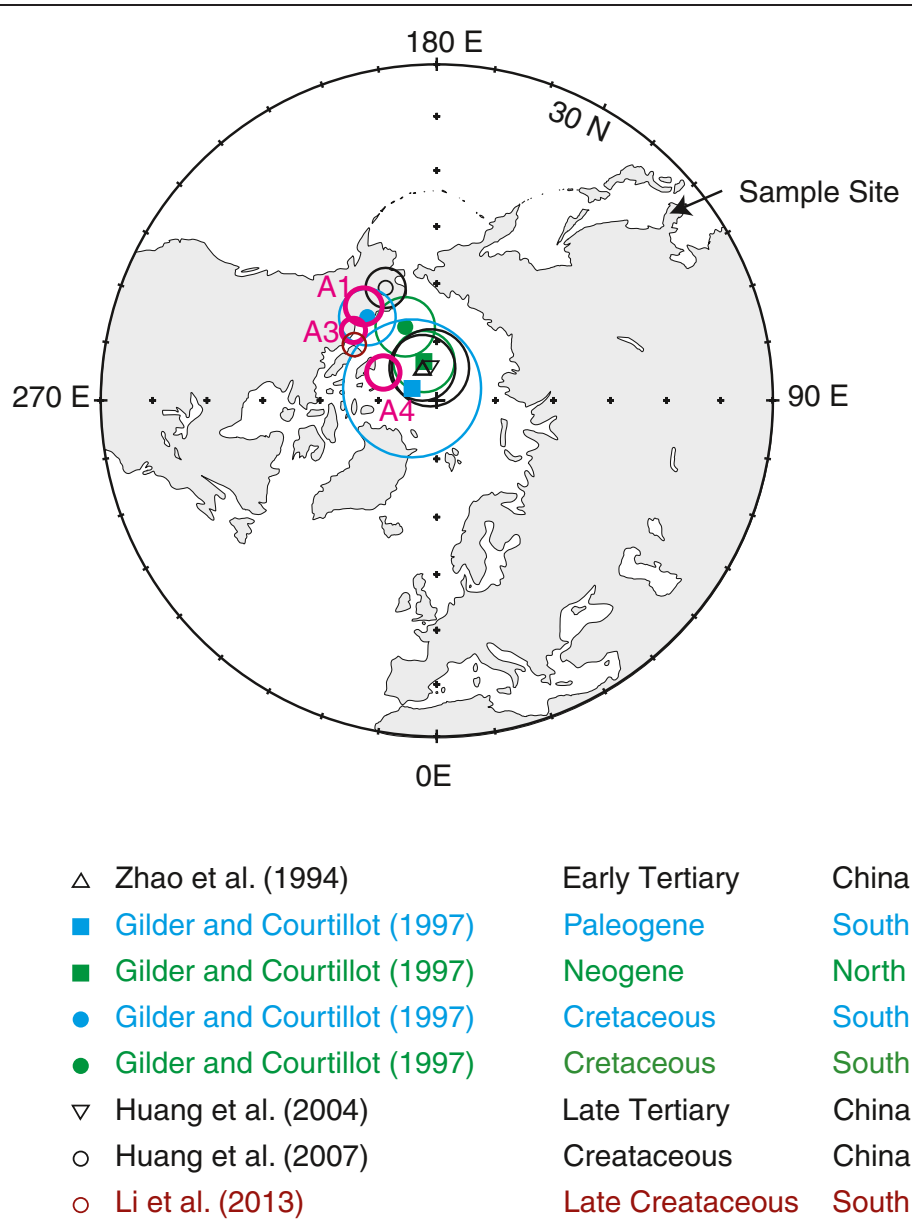

$\begin{array}{ll}\text { Early Tertiary } & \text { China } \\ \text { Paleogene } & \text { South China } \\ \text { Neogene } & \text { North China } \\ \text { Cretaceous } & \text { South China } \\ \text { Cretaceous } & \text { South China } \\ \text { Late Tertiary } & \text { China } \\ \text { Creataceous } & \text { China } \\ \text { Late Creataceous } & \text { South China }\end{array}$

Figure 10 Paleomagnetic poles of A1, A3, and A4 from the CVF, together with reference poles from China. Red circles: this study; open black triangle for early Tertiary, China (Zhao et al. 1994); solid blue squares for Paleogene, South China (Gilder and Courtillot 1997); solid green squares for Neogene, North China (Gilder and Courtillot 1997); solid blue circles for Cretaceous, China (Gilder and Courtillot 1997); solid green circles for Cretaceous, China (Gilder and Courtillot 1997); open inverted black triangle for late Tertiary, China (Huang et al. 2004); open black circle for Cretaceous, China (Huang et al. 2007); open brown circles for late Cretaceous, South China (Li et al. 2013).

1994), Paleogene to Neogene (Gilder and Courtillot 1997), and/or late Tertiary (Huang et al. 2004). The Cretaceous paleopoles of North China Block (NCB) and South China Block (SCB) are the result of averaging both Early and Late Cretaceous paleopoles of the two blocks and thus mask or smooth the details of the relative displacement between the Korean Peninsula and the NCB and SCB (Figure 10). In summary, a comparison of the paleomagnetic poles of the CVF with respect to more stable Chinese cratons suggests that neither significant shortening nor rotations are necessary.

As far as the present study is concerned, the paleomagnetic poles of the CVF show excellent coherence with coeval poles from China, suggesting that Korea has been rigidly attached to China (by implication to Eurasia) at least since the Cretaceous (Figure 10). However, earlier paleomagnetic studies on Mesozoic to Tertiary rocks from the Korean Peninsula showed vertical rotations with respect to China (e.g., Lee et al. 1987; Kim and Van der
Voo 1990; Doh and Piper 1994; Zhao et al. 1994, 1999; Doh et al. 1999, 2002; Lee et al. 1999; Zhao et al. 1999; Uno 2000; Park et al. 2003, 2005, 2007; Kim et al. 2009). Then, viable solutions to explain the various degrees of vertical rotations observed in previous paleomagnetic investigations required that individual geologic terranes of the Korean Peninsula formed in Mesozoic to Tertiary experienced different degrees of vertical rotations.

To evaluate the tectonic evolution of the Korean Peninsula, temporal evolution of vertical rotations between the observed and expected magnetic declination for all the available paleopoles documented in the peerreviewed literature with modern paleomagnetic standards was displayed (Figure 11). To estimate vertical rotation for individual study, three commonly used reference poles from China were assigned for Neogene (Zhao et al. 1994), Paleogene to Cretaceous (Huang et al. 2007), and Jurassic (Gilder et al. 1997). We limited vertical rotation analysis extending only up to Jurassic because the collision 


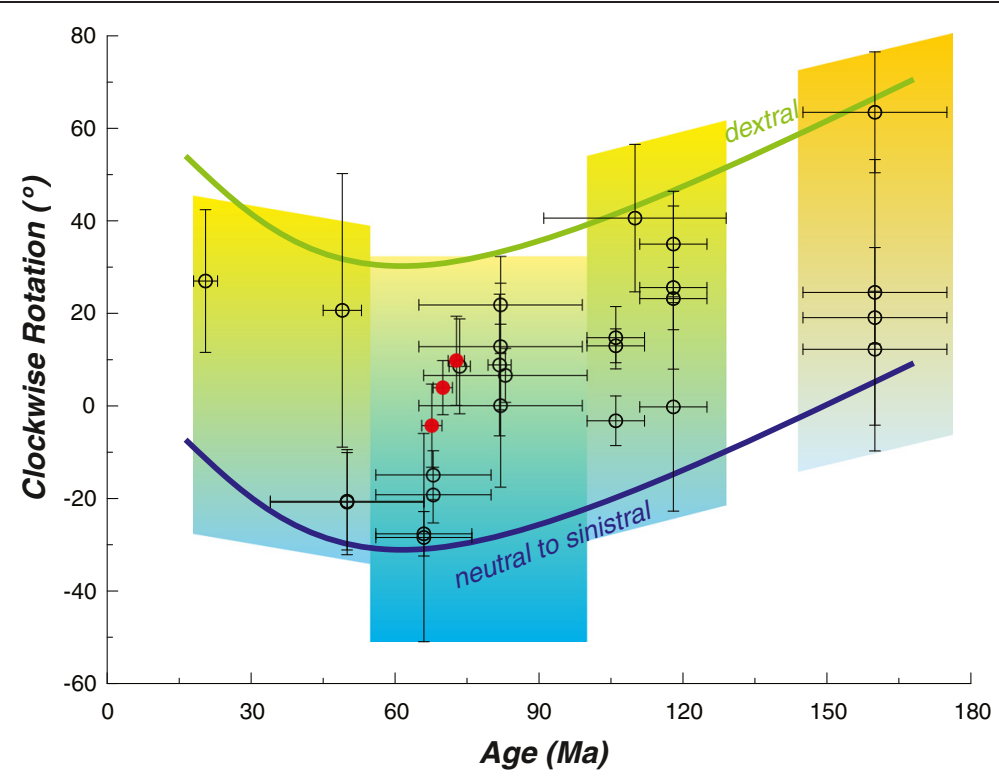

Figure 11 Variation of temporal clockwise rotations of the Korean Peninsula. Vertical rotations were calculated by comparing the observed and expected magnetic declination with respect to the three commonly used reference poles from China for Neogene (Zhao et al. 1994), Paleogene to Cretaceous (Huang et al. 2007), and Jurassic (Gilder and Courtillot 1997). Results from this study (red circles) indicate no significant rotation.

between NCB and SCB was completed by the middle Jurassic as their paleopoles are overlapping each other (Huang and Opdyke 1991; Gilder et al. 1996; Gilder and Courtillot 1997). If the Korean Peninsula was exposed to constant tectonic forcing rather than episodic tectonic processes since the Jurassic, then a linear variation of vertical rotation is expected. Instead of a linear relation, temporal evolution of vertical rotation tracks a half-cycle of sinusoidal variation with the minimum clockwise rotation at 60 to $70 \mathrm{Ma}$ (Figure 11). Prior to 60 to $70 \mathrm{Ma}$, the amount of clockwise rotations with respect to Chinese reference poles steadily decreased with time (Figure 11). The compiled data further suggest that the mode of clockwise rotations was even reversed to counterclockwise at the end of the late Cretaceous. Then, a new regime of clockwise rotations began to recover (Figure 11).

Plate motions would remain rather constant over long time intervals. However, major tectonic changes, such as reorganization of neighboring plate motions, alteration of tectonic boundary, and opening of an ocean basin, would leave small circle swath with respect to reference Euler poles. Such cusps might be reflected as changes in local vertical rotations (Figure 11). Then, what triggered a sinusoidal swing of vertical rotations in the Korean Peninsula at 60 to $70 \mathrm{Ma}$ ? Possible sources of tectonic contributor would be the two major fault systems of the Tancheng-Lujiang fault and the Korea-Taiwan strait fault (several hundred kilometers away), the nearest subduction front of the Pacific Plate (over 1,000 km away), and far-field expression of the India-Asia collision (over $4,000 \mathrm{~km}$ away) in order of increasing distance.
The first and nearest contributor may be the major faults developed in East Asia. Indeed, the Korean Peninsula is bounded by two major faults of the Tan-Lu fault to the northwest and the Korea-Taiwan strait fault to the southeast (Figure 1 inset). Both fault systems are northeastsouthwest trending sinistral in motion (Grimmer et al. 2002; Wang 2006). Such mega-sized sinistral faults could have facilitated clockwise rotations of the Korean Peninsula with respect to China, as in synthetic R-type Riedel shear. Diminishing clockwise motion since the Jurassic fits well with the period of active motion of the Tan-Lu fault (Klimetz 1983). It should be noted that similar clockwise rotations of paleomagnetic poles were also observed in Benxi area, China (Uchimura et al. 1996).

The second possible contributor would involve changes in near-field tectonic forcing of the subducting Pacific Plate beneath the Eurasian Plate. Although the exact timing and location of Izanagi ridge subduction is far from being perfectly resolved (Whittaker et al. 2007; Seton et al. 2012), the Izanagi-Pacific ridge system is estimated to have existed from 120 to $60 \mathrm{Ma}$ (Rowley 2008; van der Meer et al. 2012). Timing of the disappearance of the Izanagi-Pacific ridge system is consistent with the change in the plate motion of the Pacific from northwest (older than $62 \mathrm{Ma}$ ) to west (younger than $62 \mathrm{Ma}$ ) (Butterworth et al. 2014). It is feasible that westerly enhanced motion of the Pacific Plate around 60 to $70 \mathrm{Ma}$ restored clockwise rotations of the Korean Peninsula as the westerly subduction would accumulate a dextral shear along the NE trend fault (Figure 11). 
Such a clockwise swing was probably weakened as the new back-arc ocean is created between Japan and Korea in Miocene (Figure 11).

A third probable contributor would be far-field expressions of the India-Asia collision (Acton and Gordon 1989; Besse and Courtillot 1991; Vandamme et al. 1991; Leech et al. 2005). As initially proposed by Zhao et al. (1999), the Kula-Eurasia collision may influence the vertical rotations of the Korean Peninsula.

\section{Conclusions}

On the basis of paleomagnetic analysis of the CVF, this study demonstrates the following facts:

1. The weighted mean ages obtained by U-Pb zircon dating from the base/top of the CVF are $72.8 \pm 1.7 \mathrm{Ma} /$ $67.7 \pm 2.1 \mathrm{Ma}$, respectively. Hence, the CVF reflects late Cretaceous volcanism that predates the Paleogene.

2. Reliable paleomagnetic information was extracted from the late Cretaceous ignimbrites in Korea. Paleomagnetic mean directions and paleopoles are $D / I=19.1^{\circ} / 49.2^{\circ}\left(\alpha_{95}=4.2^{\circ}, k=76.5\right)$ and $\mathrm{VGP}=73.1^{\circ} \mathrm{N} / 232.1^{\circ} \mathrm{E}\left(A_{95}=3.7^{\circ}, N=3\right)$ for A1, $D / I=24.9^{\circ} / 52.9^{\circ}\left(\alpha_{95}=5.9^{\circ}, k=61.7\right)$ and $\mathrm{VGP}=69.4^{\circ} \mathrm{N} / 217.3^{\circ} \mathrm{E}\left(A_{95}=5.6^{\circ}, N=11\right)$ for $\mathrm{A} 3$, and $D / I=10.9^{\circ} / 50.1^{\circ}\left(\alpha_{95}=5.6^{\circ}, k=38.6\right)$ and $\mathrm{VGP}=79.8^{\circ} \mathrm{N} / 242.4^{\circ} \mathrm{E}\left(A_{95}=5.0^{\circ}, N=18\right)$ for A4.

3. VGP positions of the CVF are statistically identical to the reference poles from China in late Cretaceous to early Paleogene, indicating that Korea has been rigidly attached to China (by implication to Eurasia) at least since the Cretaceous.

4. Earlier paleomagnetic investigations on Mesozoic to Tertiary rocks from the Korean Peninsula suggest that the degrees of clockwise rotations weakened since the mid-Jurassic. Such variation might result from the influence of two major nearby strike-slip faults (the Tancheong-Luijang fault to the northwest and the Korea-Taiwan strait fault to the southeast), near-field tectonic forcing of subducting Pacific Plate, and far-field expressions of the India-Asia collision.

\section{Competing interests}

The authors declare that they have no competing interests.

\section{Authors' contributions}

DJ carried out the rock magnetic measurements and Ar/Ar dating and drafted the manuscript. YY carried out the paleomagnetic measurements, statistical analysis, and petrographic description and managed the manuscript. SD and DS conceived of the study and participated in its design and coordination. JK was in charge of the U/Pb dating and chronologic interpretation. All authors read and approved the final manuscript.

\section{Acknowledgements}

Lae Hee Han and Su Min Lee provided tremendous help in the field. Editor Xixi Zhao and two anonymous reviewers greatly improved the paper. This work was supported by the National Research Foundation of Korea (NRF) grant funded by the Korea government (MSIP) (NRF-2013R1A2A1A01004418).

\section{Author details}

'Department of Geology and Earth Environmental Sciences, Chungnam National University, 99 Daehak-ro, Daejeon 305-764, Korea. ${ }^{2}$ Department of Earth and Environmental Sciences, Korea University, 145 Anam-ro, Seoul 136-701, Korea. ${ }^{3}$ Department of Marine Sciences and Convergent Technology, Hanyang University, 55 Hanyangdaehak-ro, Ansan 425-791, Korea. ${ }^{4}$ Ochang Center, Korea Basic Science Institute, 162 Yeongudanji-ro, Ochang, Chungbuk 363-883, Korea.

Received: 27 November 2014 Accepted: 23 April 2015

Published online: 08 May 2015

\section{References}

Acton GD, Gordon RC (1989) Limits on the age on the Deccan Traps of India from paleomagnetic and plate reconstruction data and their uncertainties. J Geophys Res 94(B12):17713-17720

Besse J, Courtillot V (1991) Revised and synthetic apparent polar wander paths of the African, Eurasian, North American, and Indian plates, and true polar wander since 200 Ma. J Geophys Res 96:4029-4050

Besse J, Courtillot V (2002) Apparent and true polar wander and the geometry of the geomagnetic field over the last 200 Myr. J Geophys Res. doi:10.1029/2000JB000050

Butterworth NP, Miller RD, Quevedo L, O'Connor JM, Hoernle K, Morra G (2014) Pacific plate slab pull and intraplate deformation in the early Cenozoic. Solid Earth 5:757-777

Cluzel DJ, Lee B-J, Cadet J-P (1991) Indosinian dextral ductile fault system and synkinematic plutonism in the southwest of the Ogcheon belt (South Korea). Tectonophys 194:131-151

Doh S-J, Piper JDA (1994) Paleomagnetism of the (Upper Paleozoic-Lower Mesozoic) Pyongan Supergroup, Korea: a Phanerozoic link with the North China Block. Geophys J Int 117:850-863

Doh S-J, Suk D, Kim BY (1999) Paleomagnetic and rock-magnetic studies of Cretaceous rocks in the Eumseong Basin, Korea. Earth Planets Space 51:337-349

Doh S-J, Kim W, Suk D, Park YH, Cheong D (2002) Paleomagnetic and rock-magnetic studies of Cretaceous rocks in the Gongju Basin, Korea: implication of clockwise rotation. Geophys J Int 150:737-752

Enkin R, Yang Z, Chen Y, Courtillot V (1992) Paleomagnetic constraints on the geodynamic history of the major blocks of China from the Permian to the present. J Geophys Res 97:13953-13989

Gilder S, Zhao X, Coe R, Meng Z, Courtillot V, Besse J (1996) Paleomagnetism and tectonics of the Southern Tarim Basin, northwestern China. J Geophys Res 101(B10):22015-22031, doi:10.1029/96JB01647

Gilder S, Courtillot V (1997) Timing of the North-south China collision from new middle to late Mesozoic paleomagnetic data from the North China Block. J Geophys Res 102:17713-17727

Gilder S, Gomez J, Chen Y, Cogne JP (2008) A new paleogeographic configuration of the Eurasian landmass resolves a paleomagnetic paradox of the Tarim basin (China). Tectonics 27, TC1012, doi:10.1029/2007TC002155

Grimmer JC, Jonckheere R, Enkelmann E, Ratschbacher L, Hacker BR, Blythe AE et al (2002) Cretaceous-Cenozoic history of the southern Tan-Lu fault zone: apatite fission-track and structural constraints from the Dabie Shan (eastern China). Tectonophys 359:225-253

Huang K, Opdyke ND (1991) Paleomagnetism of Jurassic rocks from the southwestern Sichuan and the timing of the closure of the Qinling Suture. Tectonophys 200:299-316

Huang BC, Wang YC, Liu T, Yang TS, Li YA, Sun DJ et al (2004) Paleomagnetism of Miocene sediments from the Turfan Basin, Northwest China: no significant vertical-axis rotation during Neotectonic compression within the Tian Shan Range Central Asia. Tectonophys 384:1-21

Huang BC, Piper JDA, Zhang C, Li Z, Zhu RX (2007) Paleomagnetism of Cretaceous rocks in the Jiaodong Peninsula, eastern China: insight into block rotations and neotectonic deformation in eastern Asia. J Geophys Res 112, B03106, doi:10.1029/2006JB004462 
Kim GH, Van der Voo R (1990) Jurassic and Triassic paleomagnetism of South Korea. Tectonics 9:699-717

Kim W, Doh SJ, Yu Y, Lee JJ, Suk D (2009) Hydrothermal fluid-controlled remagnetization of sedimentary rocks in Korea: tectonic importance of pervasive Tertiary remagnetization. Tectonophys 474:684-695

Kirschvink JL (1980) The least squares line and plane and the analysis of paleomagnetic data. Geophys J R Astron Soc 62:699-718

Klimetz MP (1983) Speculations on the Mesozoic plate tectonic evolution of eastern China. Tectonics 2:139-166

Kobayashi T (1966) Stratigraphy of the Chosun Group in Korea and South Manchuria and its relation to the Cambro-Ordovician formations of other areas. J Faculty Sci Univ Tokyo Sect 2(14):1-84

Kobayashi T (1967) Stratigraphy of the Chosun Group in Korea and South Manchuria and its relation to the Cambro-Ordovician formations of other areas. J Faculty Sci Univ Tokyo Sect 2(14):381-383

Lee GD, Besse J, Courtillot V, Montigny R (1987) Eastern Asia in the Cretaceous: new paleomagnetic data from South Korea and a new look at Chinese and Japanese data. J Geophys Res 92:3580-3596

Lee YS, Nishimura S, Min KD (1996) High-unblocking-temperature hematite magnetizations of late Paleozoic red beds from the Ogcheon zone, southern part of the Korean Peninsula. Geophys J Int 125:266-284

Lee YS, Ishikawa N, Kim WN (1999) Paleomagnetism of Tertiary rocks on the Korean Peninsula: tectonic implications for the opening of the East Sea (Sea of Japan). Tectonophys 304:131-149

Leech ML, Singh S, Jain AK, Klemperer SL, Manickavasagam RM (2005) The onset of India-Asia continental collision: early, steep subduction required by the timing of UHP metamorphism in the western Himalaya. Earth Planet Sci Lett 234:83-97

Li YX, Shu L, Wen B, Yang Z, Ali JR (2013) Magnetic inclination shallowing problem and the issue of Eurasia's rigidity: insights following a paleomagnetic study of upper Cretaceous basalts and redbeds from SE China. Geophys J Int 194:1374-1389

Ludwig KR (2008) User's manual for Isoplot 3.6: a geochronological toolkit for Microsoft Excel. Berkeley Geochronology Center Special Publication, Berkeley

Ludwig KR (2009) User's manual for SQUID 2. Berkeley Geochronology Center Special Publication, Berkeley

Lurcock P C, Wilson G S (2012) PuffinPlot: a versatile, user-friendly program for paleomagnetic analysis. Geochem Geophys Geosys 13:Q06Z45. doi:10.1029/2012GC004098.

Ma X, Yang Z, Xing L (1993) The lower Cretaceous reference pole for North China, and its tectonic implications. Geophys J Int 115:323-331

May SR, Butler RF, Shafiquallah M, Damon PE (1986) Paleomagnetism of Jurassic volcanic rocks in the Patagonia mountains, southeastern Arizona: implications for the north American 170 Ma reference pole. J Geophys Res 91:11545-11555

McFadden PL, McElhinny MW (1988) The combined analysis of remagnetization circles and direct observations in paleomagnetism. Earth Planet Sci Lett $87: 163-189$

Néel $L$ (1955) Some theoretical aspects of rock magnetism. Adv Physiol Educ 4:191-243

Paces JB, Miller JD Jr (1993) Precise U-Pb ages of Duluth Complex and related mafic intrusions, Northeastern Minnesota: geochronological insights to physical, petrogenic, paleomagnetic, and tectonomagmatic processes associated with the 1.1 Ga midcontinent rift system. J Geophys Res 98:13997-14013

Park KH, Kim SE (1985a) Ash-flow tuffs of the Chisulryoung Volcanic Formation and associated welded tuff intrusion, Wolseong District, southern Korea. J Korea Inst Min 18:125-134

Park KH, Kim SE (1985b) A layered felsic diatreme near Wolseong, Geongsang Buk Do, Korea. J Geol Soc Korea 18:357-368

Park KH (1990) A down sag caldera associated with the Chisulryoung Volcanic Formation, near Kyeongju city, southern Korea. J Geol Soc Korea 26:213-216

Park YH, Doh S-J, Suk D (2003) Chemical remagnetization of the Upper Carboniferous-Lower Triassic Pyeongan Supergroup in the Jeongseon area, Korea: fluid migration through the Ogcheon Fold Belt. Geophys J Int 154:89-103

Park YH, Doh S-J, Ryu IC, Suk D (2005) A synthesis of Cretaceous paleomagnetic data from South Korea: tectonic implications in East Asia. Geophys J Int 162:709-724

Park YH, Doh S-J, Suk D (2007) The early Tertiary chemical remagnetization in the Bakjisan syncline, Korea: its geotectonic implications. Phys Earth Planet Inter 160:269-284
Pei J, Sun Z, Liu J, Wang X, Yang Z, Zhao Y et al (2011) A paleomagnetic study from the late Jurassic volcanics (155 Ma), North China: implications for the width of Mongol-Okhotsk ocean. Tectonophys 510:370-380

Reedman AJ, Park KH, Merriman RJ, Kim SE (1987) Primary welded tuff infilling a volcanic vent at Weolseong, Republic of Korea. Bull Volcanol 49:541-546

Reedman AJ, Park KH, Evans JA (1989) The age of granitoid intrusions and related mineralization in the Chisulryoung mountain area, south-east Korea: constraints on the age of the Chisulryoung Volcanic Formation and Yucheon Group volcanism. J Geol Soc Korea 25:51-58

Rowley DB (2008) Extrapolating oceanic age distributions: lessons from the Pacific region. J Geophys Res 116:587-598

Schlinger CM, Veblen DR, Rosenbaum JG (1991) Magnetism and magnetic mineralogy of ash flow tuffs from Yucca Mountain, Nevada. J Geophys Res 96:6035-6052

Seton M, Müller R, Zahirovic S, Gaina C, Torsvik T, Shephard S, Talsma A, Gurnis M, Turner M, Maus S (2012) Global continental and ocean basin reconstructions since 200 Ma Earth Sci Rev 113:212-270

Tauxe L, Bertram HN, Seberino C (2002) Physical interpretation of hysteresis loops: micromagnetic modeling of fine particle magnetite. Geochem Geophys Geosyst 3(10):1055, doi:10.1029/2001GC000241

Uchimura H, Kono M, Tsunakawa T, Kimura G, Wei Q, Hao T et al (1996) Paleomagnetism of late Mesozoic rocks from northern China: the role of the Tan-Lu fault in the North China Block. Tectonophys 262:301-319

Uno K (1999) Early Triassic paleomagnetic results from the Ryeongnam Block, Korean peninsula: the Eastern extension of the North China Block. Geophys Int 139:841-851

Uno K, Chang K-H (2000) Paleomagnetic results from the lower Mesozoic Daedong Supergroup in the Gyonggi Block, Korean peninsula: an eastern extension of the South China Block. Earth Planet Sci Lett 182:49-59

Uno K, Chang TW, Furukawa K (2004) Tectonic elements with South China affinity in the Korean peninsula: new early Jurassic paleomagnetic data. Geophys J Int 158:446-456

Uno K, Kaneshige Y, Furukawa K, Shinmura T, Miyoshi M (2013) Paleomagnetic investigation of rhyolitic lava: is rhyolite with clearly marked flow structure a high-fidelity geomagnetic field recorder? Earth Planets Space 65:331-336

Vandamme D, Courtillot V, Besse J, Montigny R (1991) Paleomagnetism and age determinations of the Deccan Traps (India): results of a Nagpur-Bombay Traverse and review of earlier work. Rev Geophys 29(2):159-190

van der Meer DG, Torsvik TH, Spakman W, van Hinsbergen DJJ, Amaru ML (2012) Intra-Panthalassa ocean subduction zones revealed by fossil arcs and mantle structure. Nat Geosci 5:215-219

Wang Y (2006) The onset of the Tan-Lu fault movement in eastern China: constraints from zircon (SHRIMP) and ${ }^{40} \mathrm{Ar} /{ }^{39} \mathrm{Ar}$ dating. Terra Nova 18:423-431

Whittaker JM, Muller RD, Leitchenkov G, Stagg H, Sdrolias M, Gaina C et al (2007) Major Australian-Antarctic plate reorganization at Hawaiian-Emperor bend time. Science 318:83-86

Wolff JA, Wright JV (1981) Rheomorphism of welded tuffs. J Volcanol Geotherm Res 10:13-34

Yang Y, Besse J (2001) New Mesozoic apparent polar wandering path for south China: tectonic consequences. J Geophys Res 106:8493-8520

Yi K, Cheong C-S, Kim J, Kim N, Jeong Y-J, Cho M (2012) Late Paleozoic to Early Mesozoic arc-related magmatism in southeastern Korea: SHRIMP zircon geochronology and geochemistry. Lithos 153:129-141

York D (1969) Least squares fitting of a straight line with correlated errors. Earth Planet Sci Lett 5:320-324

Zhao X, Coe RS, Zhou Y, Hu S, Wu H, Kuang G et al (1994) Tertiary paleomagnetism of North and South China and a reappraisal of late Mesozoic paleomagnetic data from Eurasia: implications for the Cenozoic tectonic history of Asia. Tectonophys 235:181-203

Zhao X, Coe RS, Chang K-H, Park S-O, Omarzai SK, Zhu R et al (1999) Clockwise rotations recorded in early Cretaceous rocks of South Korea: implications for tectonic affinity between the Korean Peninsula and North China. Geophys J Int 139:447-463 